\title{
The Effect of Aerobic Exercise in Ambient Particulate Matter on Lung Tissue Inflammation and Lung Cancer
}

\author{
Mohamad Fashi ${ }^{1}$; Hamid Agha Alinejad ${ }^{1,}$; Hasan Asilian Mahabadi ${ }^{2}$ \\ ${ }^{1}$ Department of Physical Education and Sports Sciences, Tarbiat Modares University, Tehran, IR Iran \\ ${ }^{2}$ Deptartment of Occupational Health Engineering, Tarbiat Modares University, Tehran, IR Iran \\ ${ }^{*}$ Corresponding author: Hamid Agha Alinejad, Department of Physical Education and Sports Sciences, Tarbiat Modares University, Tehran, IR Iran. Tel: +98-9124946181, \\ E-mail: halinejad@modares.ac.ir
}

Received: January 14, 2015; Revised: January 20, 2015; Accepted: January 28, 2015

\begin{abstract}
Background: Exposure to Air pollution PM10 results in lung inflammation increased risk of lung cancer. Regular aerobic exercise improves the inflammatory status in different lung diseases. However, the effects of long-term aerobic exercise on the pulmonary response to PM10 have not been investigated.

Objectives: The present study evaluated the effect of aerobic exercise on the lung inflammatory and risk of lung cancer of rat exposed to PM10 carbon black.

Materials and Methods: Twenty four adult male Wistar rats were divided into 4 groups: A: control (without exposure PM10 and aerobic exercise; $n=6$ ), B: aerobic exercise (five times per week for 4 weeks; $n=6)$, C: exposure to PM10 carbon black $\left(5 \mathrm{mg} / \mathrm{m}^{3} ;\right.$ per rat; $\left.n=6\right)$, D: and aerobic exercise concomitantly with exposure to PM10 carbon black $(n=6)$. The gene expression of TLR4, NF- $\mathrm{B} B$ and TNF- $\alpha$ were analyzed in lung tissue by Real time-PCR. In order to determine the significant differences between groups, one way ANOVA and LSD post hoc and Kruskal-Vallis test were used.

Results: Aerobic exercise inhibited the PM10 -induced increase in the gene expression of TLR4, NF- $-\mathrm{B}$ and TNF- $\alpha$. But there was significant different only between B and C groups for TNF- $\alpha$ and NF- $\mathrm{B}(\mathrm{P}=0.047,0.014$, respectively).

Conclusions: We conclude that four week aerobic exercise presents protective effects in a rat model of PM10 carbon black-induced lung inflammation and risk of lung cancer. Our results indicate a need for human studies that evaluate the lung Responses to aerobic exercise chronically performed in polluted areas.
\end{abstract}

Keywords: Lung, Inflammation; Aerobic Exercise; PM10

\section{Background}

Inhalation of particulate matter (PM) from fossil fuel combustion is associated with adverse health effects, including reduced lung function (1) and increased mortality (2). Although the mechanism for PM-induced health effects is not fully defined, animal models and in vitro studies suggest that pro-inflammatory cytokine release from airway cells is an important factor (3). Inflammation may play a role in the etiology of lung cancer. Environmental agents associated with elevated lung cancer risk, such as ambient particulate matter, may damage the lung by inducing chronic inflammation. Lung cancer risk is elevated in individuals with emphysema $(4,5)$, interstitial lung disease (6), and asthma (7), which could similarly reflect effects of the underlying inflammatory disorders.

Induction of pro-inflammatory mediators by alveolar macrophages exposed to ambient air particulate matter has been suggested to be a key factor in the pathogenesis of inflammatory and diseases in the lungs. However, receptors and mechanisms underlying these responses have not been fully elucidated. Different contributing physiological and psychosocial factors have been proposed (8). A few prior studies have examined lung cancer risk in relation to polymorphisms in the genes coding for inflammation pathway signaling molecules, such as Interleukin $1 \beta$ (IL-1 $\beta$ ) (9-11), IL-1 receptor antagonist (IL-1RN) $(12,13)$, IL-6 $(10,14)$, IL-10 (15), cyclooxygenase 2 (14), and tumor necrosis factor- $\alpha$ (16). These inflammatory cytokines are regulated by the pro-inflammatory transcription factor, nuclear factor NF- $\kappa$ B (8).

Given the close interaction between the external environment and the lung, TLRs have been implicated in lung-associated immune responses, including airway hyper responsiveness (AHR) and allergic asthma (17). Dysfunction and unregulated activation of the TLR pathway can contribute to decreased lung function and the pathogenesis of acute and chronic lung inflammatory diseases (18). TLR activation, can occur via two pathways: 1- the Myeloid Differentiation primary-response protein 88 (MyD88)-dependent pathway, and 2- the MyD88-indepen-

Copyright (C) 2015, Iranian Journal of Cancer Prevention. This is an open-access article distributed under the terms of the Creative Commons Attribution-Non Commercial 4.0 International License (http://creativecommons.org/licenses/by-nc/4.0/) which permits copy and redistribute the material just in noncommercial usages, provided the original work is properly cited. 
Fashi Met al.

dent pathway. These two pathways correspond to early and late-phase NF-kB signaling and pathway-specific induction of pro-inflammatory cytokines and chemokines $(19,20)$. Inflammation play an important role in the etiology of lung cancer.

Regular aerobic exercise results in multiple health benefits, including improvement of cardiorespiratory fitness and quality of life, reduction of obesity and blood pressure, and increased longevity $(21,22)$. When performed chronically on a regular basis, aerobic exercise also reduces oxidative stress systemically (23) in different diseases, such as heart diseases, type 2 diabetes, rheumatic arthritis, and alzheimer and parkinson diseases (23), as well as in the airway epithelial cells of animals with long-term allergic lung inflammation (24). Chronic practice of regular exercise exerts a marked anti-inflammatory effect in different models of pulmonary diseases, such as in asthma models (25-28), acute respiratory distress syndrome $(29,30)$, and chronic obstructive pulmonary disease (31).

Studies that have investigated the effects of exposure to air pollutants during exercise have suggested that people exercising in polluted environments are at increased risk of respiratory and cardiovascular morbidity related to air pollution owing to an exercise-induced amplification in respiratory uptake, lung deposition, and toxicity of inhaled pollutants (32-35). Exercise may increase the likelihood of an adverse effect by increasing the dose of pollutants delivered to target sites in the lungs as ventilation increases to meet metabolic demands (36). However, these studies do not take into account the potential anti-inflammatory and health effects of exercising in air pollution (37), which could inhibit the pro-inflammatory events induced by air pollution.

\section{Objectives}

Therefore, the aim of this study was to investigate the effects of 4 weeks of aerobic exercise performed in association with carbon black PM10 exposure on lung tissue inflammation and lung cancer.

\section{Materials and Methods}

In all experiments, the Tarbiat Modares university guidelines for animal care was followed. This study was approved by the Tarbiat Modares University of Tehran (code number: 62.2987).

\subsection{Animals}

Twenty four adult male Wistar rats aged 8 weeks were obtained from Pasteur Institute of Iran and randomly divided into the 4 groups: $\mathrm{A}$; control (without exposure carbon black PM10 and aerobic exercise; $n=6$ ), B; aerobic exercise (five times per week for 4 weeks; $n=6$ ), C; exposure to carbon black PM10 ( $5 \mathrm{mg} / \mathrm{m}^{3}$; per rat; $\mathrm{n}=6$ ), D; aerobic exercise concomitantly with exposure to carbon black
PM10 $(n=6)$. Rats were housed in cages under controlled environment $\left(23^{\circ} \mathrm{C}\right.$ and 12 hour light-dark cycle) with free access to normal chow and tap water.

\subsection{Exposure to Carbon Black PM10}

Figure 1 shows the inhalation chamber at the laboratory of Tarbiat Modares university (Falonak) where inhalation exposure was carried out. Carbon black dust (38) obtained from Iran-carbon factory. Rats in groups of C and $\mathrm{D}$ were exposed to carbon black in the inhalation chamber at nominal concentrations of $5 \mathrm{mg} / \mathrm{m}^{3}$ for $2 \mathrm{~h} /$ day, 5 days per week for a total of 4 weeks. The control rats were exposed to clean, filtered air containing no carbon black for the same period. The concentrations, size and shape of $\mathrm{CB}$ particle were monitored once time weekly by Grimm Aerosol Technique (GmbH and Co. KG. Dorfstraße 9 - 83404 Ainring-Germany (and light microscope (Acc.VSpot magn. 25.0 KV 3.4.5000 x), respectively.

\subsection{Exercise Treadmill Test and Training}

Animals in B and D groups were adapted to the treadmill for rat (will running treadmill, Lafayette American) training for 3 days ( 15 minutes, $20 \mathrm{~m} / \mathrm{min}$ ). On the fourth day, the individual maximal exercise capacity test was performed with a 5-minute warm-up $(6 \mathrm{~m} / \mathrm{min})$ and followed by an increase in treadmill speed $(3 \mathrm{~m} /$ min every 3 minutes) until animal exhaustion (i.e. when they were not able to run voluntarily after 3 mechanical stimuli) $(24,27,28)$. The maximal exercise capacity $(100 \%)$ was defined as the maximum speed reached by each animal. The physical test was performed for each rat individually. The speed average of each group was calculated, and then the rats were submitted to treadmill training as a mean speed of the group workload. rats were trained at low intensity, corresponding to $50 \%$ of the initial maximal speed obtained in the exercise test, for 60 minutes, five times per week, as previously described $(24,27,28)$.

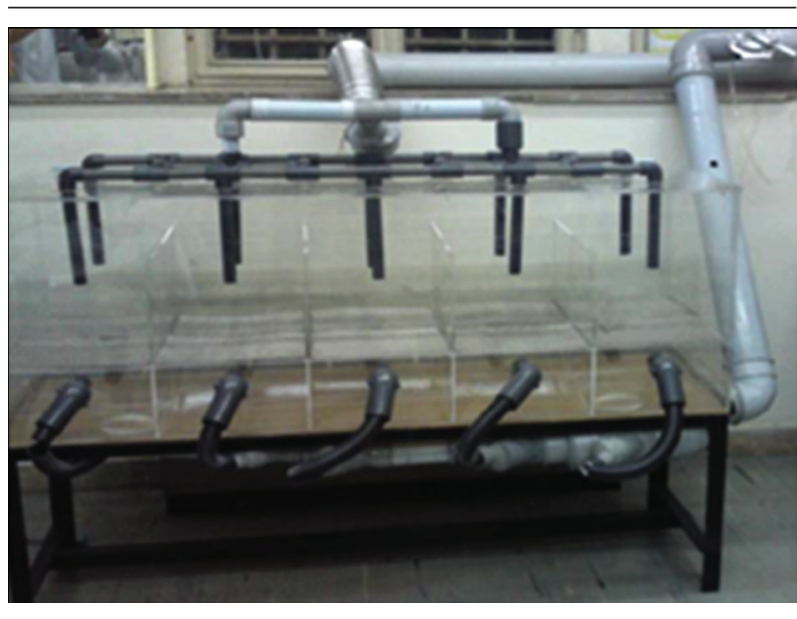

Figure 1. Inhalation Chamber Used for Whole-Body Inhalation Exposure to Carbon Black PM10 
Fashi Metal.

\subsection{Analysis of mRNA Expression TLR4, NF- $\kappa B$ and TNF- $\alpha$ by RT-PCR}

After sacrificed rat and total lung tissue, RNA was isolated using Trizolereagent (Qiagen, Germany), according to the manufacturer's instructions. The RNA samples were subjected to reverse transcription using thermo scientific revert aid first strand cDNA synthesis kit (Ferementase). In the subsequent step, the cDNAs were used as templates to perform real-time PCR using SYBR green PCR master mix (SYBR green I,) by step one ABI system (Applied Biosystem). The crossing threshold values assessed by the real-time PCR were evaluated for the transcripts and normalized to the results for GAPDH mRNA. The corresponding primer pairs for TLR4, NF- $\mathrm{B}$, and TNF- $\alpha$ and GAPDH (housekeeping gene) were listed in Table 1.

\subsection{Real-Time PCR}

All of the tests were repeated two times in each group. The threshold cycle $(\mathrm{Ct})$ for each specific gene, corresponding housekeeping gene (GAPDH) and their differences $(\Delta \mathrm{Ct})$ were determined and then evaluated gene expression changes using $2^{-\Delta \Delta C T}$ formula.

\subsection{Statistical Analysis}

Results are expressed as Mean \pm SD. Differences in body weight between pre and post interventions were examined by 2-tailed t-test. In order to determine the significant differences between groups one way ANOVA and LSD post hoc test and Kruskal-Vallis test after examined normal distribution of data by Kolmogorov-Smirnov test were used. $\mathrm{P}<0.05$ were considered statistically significant.

\section{Results}

Body weight: There were significant differences among the A (control) and C (PM10 exposure only) groups in body weight pre and post interventions. The mean of increase in body weight in C group was higher than A, B and D groups (Table 2).
4.1. Effects of Aerobic Exercise and Carbon Black PM10 Exposure on Gene Expression TLR4. NF- $\mathrm{KB}$ and TNF- $\alpha$

Presented data in Figure 2 demonstrate that PM10 carbon black exposure increased the gene expression TLR4, $N F-\kappa B$ and TNF- $\alpha$ in lung tissue compared with all of the other groups $(\mathrm{P} \leq 0.05)$ and that aerobic exercise in carbon black PM10 exposure decreased the expression of these cytokine compared with the carbon black PM10 exposure group $(\mathrm{P} \leq 0.05)$. One way ANOVA also demonstrated that carbon black PM10 exposure presented a significant effect on the TNF- $\alpha(\mathrm{P}=0.047)$ and NF- $\kappa \mathrm{B}(\mathrm{P}=$ $0.014)$. No significant effect was observed on the gene expression TLR4 by Kruskal-Vallis test $(\mathrm{P}=0.325)$.

Table 1. Primer Sequences Used in Real-Time PCR

\begin{tabular}{|c|c|}
\hline Gene & Primer Sequence \\
\hline \multicolumn{2}{|l|}{ TLR4 } \\
\hline Forward & $5^{-}$-AATCCCTGCATAGAGGTACTTCCTAAT - $3^{-}$ \\
\hline Reverse & $5^{\circ}$-CTCAGATCTAGGTTCTTGGTTGAATAAG -3’ \\
\hline \multicolumn{2}{|l|}{ NF-kB } \\
\hline Forward & $5^{\prime}$-AACACTGCCGAGCTCAAGAT - $3^{\prime}$ \\
\hline Reverse & $5^{\prime}$-CATCGGCTTGAGAAAAGGAG - $3^{\prime}$ \\
\hline \multicolumn{2}{|l|}{ TNF- $\alpha$} \\
\hline Forward & $5^{\prime}$-GACCCTCACACTCAGATCATCTTC - $3^{\prime}$ \\
\hline Reverse & $5^{\prime}$-TGCTACGACGTGGGCTACG - $3^{-}$ \\
\hline \multicolumn{2}{|l|}{ GAPDH } \\
\hline Forward & $5^{-}$-GACATGCCGCCTGGAGAAAC - $3^{-}$ \\
\hline Reverse & $5^{\prime}$-AGCCCAGGATGCCCTTTAGT - $3^{-}$ \\
\hline
\end{tabular}

Table 2. Body Weight of Animal's Pre and Post Intervention ${ }^{\text {a }}$

\begin{tabular}{lcccc}
\hline Groups & Initial Test & Final Test & Final-Initial Test & PValue \\
\hline A, Control & $285.83 \pm 25.55$ & $324.33 \pm 27.12$ & $38.50 \pm 1.57$ & $0.045^{\mathrm{b}}$ \\
\hline B, Exercise & $279.17 \pm 32.55$ & $304.33 \pm 43.31$ & $25.16 \pm 10.76$ & 0.090 \\
\hline C, PM10 & $270.50 \pm 27.12$ & $311.17 \pm 36.66$ & $40.67 \pm 9.54$ & $0.023^{\mathrm{b}}$ \\
\hline D, exe+PM10 & $281.67 \pm 22.73$ & $315.67 \pm 33.23$ & $34.00 \pm 10.50$ & 0.101 \\
\hline
\end{tabular}

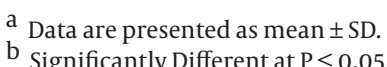


Fashi Metal.

Figure 2. Effects of Aerobic Exercise and Carbon Black PM10 Exposure on Gene Expression TLR4, NF- $\kappa B$ and TNF- $\alpha$
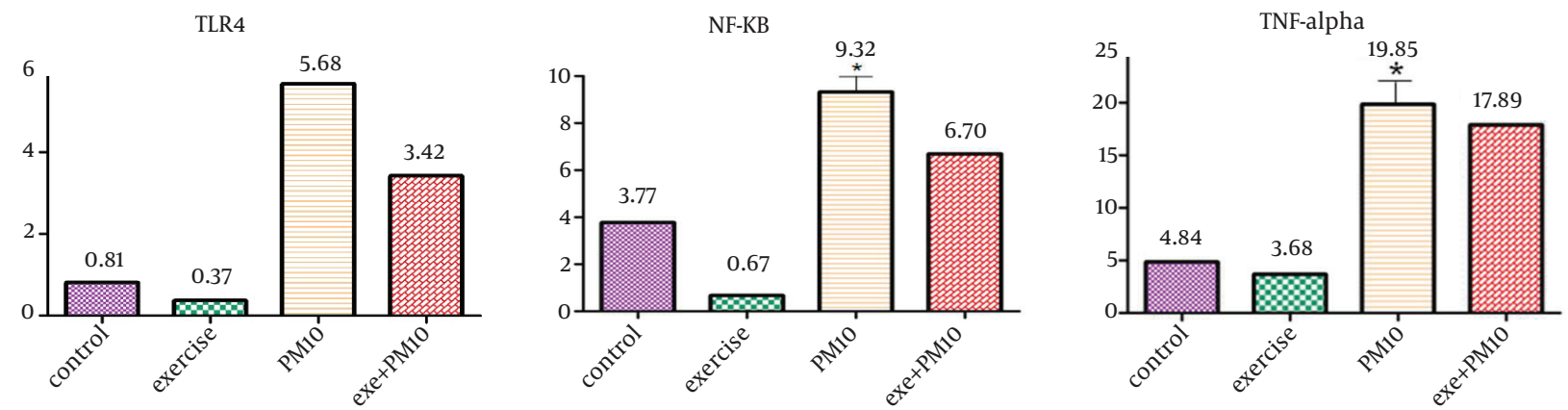

Asterisk Indicates Treatments That are Significantly Different at $\mathrm{P} \leq 0.05$ Compared With all of the Groups.

\section{Discussion}

In the present study, we demonstrated that aerobic exercise inhibits lung inflammation and pro-inflammatory cytokine release in lung tissue in an experimental model of PM10 carbon black-induced lung inflammation.

Considerable epidemiological and toxicological studies have established a clear link between exposure to air pollution particles and adverse pulmonary health effects. Several experimental and human studies have demonstrated that increased levels of air pollution associated with pulmonary inflammation $(37,38)$. The association between ambient air pollution particles exposure and lung cancer risk has been investigated in prospective studies and the results are generally consistent, indicating that long-term exposure to air pollution may cause lung cancer.

Gene expression analysis identified the association with the effect of PM10 carbon black on the innate immune response. PM10 carbon black exposure increased the gene expression TLR4, NF- $\kappa$ B and TNF- $\alpha$ in lung tissue. TLR4 activation is corresponded to NF- $\kappa B$ signaling and pathway-specific induction of pro-inflammatory cytokines and chemokines or interferon signaling (39).

An extensive research in recent years has been indicated that chronic inflammation leads to various chronic disorders associated with cancer (40-42). A central role in the induction of chronic inflammation is played by a set of genes encoding pro-inflammatory cytokines such as IL-1, IL-2, IL-6, and TNF- $\alpha$ and monocyte chemotactic Protein 1 that are regulated by the transcription factor $(\mathrm{NF}-\kappa \mathrm{B})(43-45)$.

Particulate matter exposure could effect on Obesity (46). These conditions are associated with derangements in the interplay between metabolic and immune processes and inflammation (47). The authors observed significant increase in body weight with PM10 carbon black exposure which could explain the increased inflammation can be caused by PM10 exposure.
Studies have suggested that potential anti-inflammatory effects of aerobic exercise could inhibit the pro-inflammatory events induced by air pollution. The anti-inflammatory effects of exercise (48-50) have focused on three possible mechanisms: the reduction in visceral fat mass; increased production and release of anti-inflammatory cytokines from contracting skeletal muscle (such molecules are termed myokines (48-51); and reduced expression of Toll-like receptors (TLRs) on monocytes and macrophages (52). In the present study, aerobic exercise in PM10 carbon black exposure decreased the gene expression TLR4, NF- $\mathrm{BB}$ and TNF- $\alpha$ in lung tissue and also body weight of animals. Although this change in gene expression was slight, however this result can be clinically important.

We conclude that low-intensity aerobic exercise presents protective effects from PM10 carbon black-induced lung inflammation. Future studies should therefore be directed towards better defining the mechanism involved in the induction of symptoms by inflammatory molecules and risk of cancer in exposure to air pollution particles.

\section{Acknowledgements}

We would like to thank the members of this research for their assistance in conducting this study. Special thanks to Amir Abbas Mofidi for assistance in construct chamber and PM10 simulator system.

\section{Authors' Contributions}

Mohamad Fashi designed and wrote this article and collected and analyzed the data, with Dr. Hamid Agha Alinejad and Dr. Hasan Asilian Mahabadi. All authors read and approved the final manuscript. 


\section{Conflict of Interest}

The authors made no disclosures.

\section{References}

1. Gauderman WJ, Avol E, Gilliland F, Vora H, Thomas D, Berhane K, et al. The effect of air pollution on lung development from 10 to 18 years of age. N Engl JMed. 2004;351(11):1057-67.

2. Brunekreef B, Beelen R, Hoek G, Schouten L, Bausch-Goldbohm S, Fischer P, et al. Effects of long-term exposure to traffic-related air pollution on respiratory and cardiovascular mortality in the Netherlands: the NLCS-AIR study. Res Rep Health Eff Inst. 2009;(139):5-71.

3. Knol AB, de Hartog JJ, Boogaard H, Slottje P, van der Sluijs JP, Lebret $\mathrm{E}$, et al. Expert elicitation on ultrafine particles: likelihood of health effects and causal pathways. Part Fibre Toxicol. 2009;6:19.

4. Ballaz S, Mulshine JL. The potential contributions of chronic inflammation to lung carcinogenesis. Clin Lung Cancer. 2003;5(1):46-62.

5. Yang P, Bamlet WR, Sun Z, Ebbert JO, Aubry MC, Krowka MJ, et al. Alpha1-antitrypsin and neutrophil elastase imbalance and lung cancer risk. Chest. 2005;128(1):445-52.

6. Daniels CE, Jett JR. Does interstitial lung disease predispose to lung cancer? Curr Opin Pulm Med. 2005;11(5):431-7.

7. Santillan AA, Camargo CJ, Colditz GA. A meta-analysis of asthma and risk of lung cancer (United States). Cancer Causes Control. 2003;14(4):327-34.

8. Gupta SC, Kim JH, Kannappan R, Reuter S, Dougherty PM, Aggarwal BB. Role of nuclear factor kappaB-mediated inflammatory pathways in cancer-related symptoms and their regulation by nutritional agents. Exp Biol Med (Maywood). 2011;236(6):658-71.

9. Zienolddiny S, Ryberg D, Maggini V, Skaug V, Canzian F, Haugen A. Polymorphisms of the interleukin- 1 beta gene are associated with increased risk of non-small cell lung cancer. Int J Cancer. 2004;109(3):353-6.

10. Campa D, Hung RJ, Mates D, Zaridze D, Szeszenia-Dabrowska N, Rudnai $\mathrm{P}$, et al. Lack of association between polymorphisms in inflammatory genes and lung cancer risk. Cancer Epidemiol Biomarkers Prev. 2005;14(2):538-9.

11. Lee KM, Shen M, Chapman RS, Yeager M, Welch R, He X, et al. Polymorphisms in immunoregulatory genes, smoky coal exposure and lung cancer risk in Xuan Wei, China. Carcinogenesis. 2007;28(7):1437-41.

12. Lind H, Zienolddiny S, Ryberg D, Skaug V, Phillips DH, Haugen A. Interleukin 1 receptor antagonist gene polymorphism and risk of lung cancer: a possible interaction with polymorphisms in the interleukin 1 beta gene. Lung Cancer. 2005;50(3):285-90.

13. Hu Z, Shao M, Chen Y, Zhou J, Qian J, Xu L, et al. Allele 2 of the interleukin-1 receptor antagonist gene (IL1RN*2) is associated with a decreased risk of primary lung cancer. Cancer Lett. 2006;236(2):269-75.

14. Campa D, Zienolddiny S, Maggini V, Skaug V, Haugen A, Canzian F. Association of a common polymorphism in the cyclooxygenase 2 gene with risk of non-small cell lung cancer. Carcinogenesis. 2004;25(2):229-35.

15. Shih CM, Lee YL, Chiou HL, Hsu WF, Chen WE, Chou MC, et al. The involvement of genetic polymorphism of IL-10 promoter in nonsmall cell lung cancer. Lung Cancer. 2005;50(3):291-7.

16. Shih CM, Lee YL, Chiou HL, Chen W, Chang GC, Chou MC, et al. Association of TNF-alpha polymorphism with susceptibility to and severity of non-small cell lung cancer. Lung Cancer. 2006;52(1):15-20.

17. Basu S, Fenton MJ. Toll-like receptors: function and roles in lung disease. Am J Physiol Lung Cell Mol Physiol. 2004;286(5):L887-92.

18. Lafferty EI, Qureshi ST, Schnare M. The role of toll-like receptors in acute and chronic lung inflammation. JInflamm (Lond). 2010;7:57.

19. Chen K, Xiang Y, Yao X, Liu Y, Gong W, Yoshimura T, et al. The active contribution of Toll-like receptors to allergic airway inflammation. Int Immunopharmacol. 2011;11(10):1391-8.

20. Beg AA. Endogenous ligands of Toll-like receptors: implications for regulating inflammatory and immune responses. Trends Immunol. 2002;23(11):509-12.

21. Kokkinos P, Myers J. Exercise and physical activity: clinical outcomes and applications. Circulation. 2010;122(16):1637-48.

22. Lee DC, Pate RR, Lavie CJ, Sui X, Church TS, Blair SN. Leisure-time running reduces all-cause and cardiovascular mortality risk. $J$ Am Coll Cardiol. 2014;64(5):472-81.

23. Ji LL. Modulation of skeletal muscle antioxidant defense by exercise: Role of redox signaling. Free Radic Biol Med. 2008;44(2):142-52.

24. Vieira RP, Toledo AC, Ferreira SC, Santos AB, Medeiros MC, Hage M, et al. Airway epithelium mediates the anti-inflammatory effects of exercise on asthma. Respir Physiol Neurobiol. 2011;175(3):383-9.

25. Pastva A, Estell K, Schoeb TR, Atkinson TP, Schwiebert LM. Aerobic exercise attenuates airway inflammatory responses in a mouse model of atopic asthma. JImmunol. 2004;172(7):4520-6.

26. Vieira RP, Claudino RC, Duarte AC, Santos AB, Perini A, Faria Neto $\mathrm{HC}$, et al. Aerobic exercise decreases chronic allergic lung inflammation and airway remodeling in mice. Am J Respir Crit Care Med. 2007;176(9):871-7.

27. Vieira RP, de Andrade VF, Duarte AC, Dos Santos AB, Mauad T, Martins MA, et al. Aerobic conditioning and allergic pulmonary inflammation in mice. II. Effects on lung vascular and parenchymal inflammation and remodeling. Am J Physiol Lung Cell Mol Physiol. 2008;295(4):L670-9.

28. Vieira RP, Duarte AC, Santos AB, Medeiros MC, Mauad T, Martins MA, et al. Exercise reduces effects of creatine on lung. Int J Sports Med. 2009;30(9):684-90.

29. Mussi RK, Camargo EA, Ferreira T, De Moraes C, Delbin MA, Toro IF, et al. Exercise training reduces pulmonary ischaemia-reperfusioninduced inflammatory responses. Eur Respir J. 2008;31(3):645-9.

30. Ramos DS, Olivo CR, Quirino Santos Lopes FD, Toledo AC, Martins MA, Lazo Osorio RA, et al. Low-intensity swimming training partially inhibits lipopolysaccharide-induced acute lung injury. Med Sci Sports Exerc. 2010;42(1):113-9.

31. Toledo AC, Magalhaes RM, Hizume DC, Vieira RP, Biselli PJ, Moriya HT, et al. Aerobic exercise attenuates pulmonary injury induced by exposure to cigarette smoke. Eur Respir J. 2012;39(2):254-64.

32. Campbell ME, Li Q, Gingrich SE, Macfarlane RG, Cheng S. Should people be physically active outdoors on smog alert days? Can Public Health. 2005;96(1):24-8.

33. Jacobs L, Nawrot TS, de Geus B, Meeusen R, Degraeuwe B, Bernard A, et al. Subclinical responses in healthy cyclists briefly exposed to traffic-related air pollution: an intervention study. Environ Health. 2010;9:64.

34. Patel H, Eo S, Kwon S. Effects of diesel particulate matters on inflammatory responses in static and dynamic culture of human alveolar epithelial cells. Toxicol Lett. 2011;200(1-2):124-31.

35. Strak M, Boogaard H, Meliefste K, Oldenwening M, Zuurbier $\mathrm{M}$, Brunekreef $\mathrm{B}$, et al. Respiratory health effects of ultrafine and fine particle exposure in cyclists. Occup Environ Med. 2010;67(2):118-24.

36. Daigle CC, Chalupa DC, Gibb FR, Morrow PE, Oberdorster G, Utell MJ, et al. Ultrafine particle deposition in humans during rest and exercise. Inhal Toxicol. 2003;15(6):539-52.

37. Giles LV, Koehle MS. The health effects of exercising in air pollution. Sports Med. 2014;44(2):223-49.

38. Bai Y, Brugha RE, Jacobs L, Grigg J, Nawrot TS, Nemery B. Carbon loading in airway macrophages as a biomarker for individual exposure to particulate matter air pollution - A critical review. Environ Int. 2014;74C:32-41.

39. Zhao H, Barger MW, Ma JK, Castranova V, Ma JY. Cooperation of the inducible nitric oxide synthase and cytochrome P450 1A1 in mediating lung inflammation and mutagenicity induced by diesel exhaust particles. Environ Health Perspect. 2006;114(8):1253-8.

40. Zhao H, Ma JK, Barger MW, Mercer RR, Millecchia L, SchweglerBerry D, et al. Reactive oxygen species- and nitric oxide-mediated lung inflammation and mitochondrial dysfunction in wild-type and iNOS-deficient mice exposed to diesel exhaust particles. $J$ Toxicol Environ Health A. 2009;72(8):560-70.

41. Akira S, Takeda K. Toll-like receptor signalling. Nat Rev Immunol. 2004;4(7):499-511. 
42. Balkwill F, Mantovani A. Inflammation and cancer: back to Virchow? Lancet. 2001;357(9255):539-45.

43. Balkwill F, Charles KA, Mantovani A. Smoldering and polarized inflammation in the initiation and promotion of malignant disease. Cancer Cell. 2005;7(3):211-7.

44. Coussens LM, Werb Z. Inflammation and cancer. Nature. 2002;420(6917):860-7.

45. Greten FR, Eckmann L, Greten TF, Park JM, Li ZW, Egan LJ, et al. IKKbeta links inflammation and tumorigenesis in a mouse model of colitis-associated cancer. Cell. 2004;118(3):285-96.

46. Luo JL, Maeda S, Hsu LC, Yagita H, Karin M. Inhibition of NF-kappaB in cancer cells converts inflammation- induced tumor growth mediated by TNFalpha to TRAIL-mediated tumor regression. Cancer Cell. 2004;6(3):297-305.

47. Pikarsky E, Porat RM, Stein I, Abramovitch R, Amit S, Kasem S, et al. NF-kappaB functions as a tumour promoter in inflammationassociated cancer. Nature. 2004;431(7007):461-6.

48. Xu X, Yavar Z, Verdin M, Ying Z, Mihai G, Kampfrath T, et al. Effect of early particulate air pollution exposure on obesity in mice: role of p47phox. Arterioscler Thromb Vasc Biol. 2010;30(12):2518-27.

49. Ahmad T, Chasman DI, Buring JE, Lee IM, Ridker PM, Everett BM Physical activity modifies the effect of LPL, LIPC, and CETP polymorphisms on HDL-C levels and the risk of myocardial infarction in women of European ancestry. Circ Cardiovasc Genet. 2011;4(1):74-80.

50. Mathur N, Pedersen BK. Exercise as a mean to control low-grade systemic inflammation. Mediators Inflamm. 2008;2008:109502.

51. Flynn MG, McFarlin BK. Toll-like receptor 4: link to the anti-inflammatory effects of exercise? Exerc Sport Sci Rev. 2006;34(4):176-81.

52. Pedersen BK, Febbraio MA. Muscle as an endocrine organ: focus on muscle-derived interleukin-6. Physiol Rev. 2008;88(4):1379-406. 